\title{
Influence of sociodemographic and clinical characteristics on the quality of life of patients with schizophrenia
}

\author{
Influência das características sociodemográficas e clínicas na \\ qualidade de vida dos indivíduos com esquizofrenia \\ Influencia de las características sociodemográficas y clínicas en la \\ calidad de vida de los individuos con esquizofrenia
}

Lara Guedes de Pinhoํ, Anabela Pereira ${ }^{1}$, Cláudia Chaves ${ }^{2}$

How to cite this article:

Pinho LG, Pereira A, Chaves C. Influence of sociodemographic and clinical characteristics on the quality of life of patients with schizophrenia. Rev Esc Enferm USP. 2017;51:e03244. DOI: http://dx.doi.org/10.1590/S1980-220X2016031903244

${ }^{1}$ Universidade de Aveiro, Departamento de Educação e Psicologia, Campus Universitário de Santiago, Aveiro, Portugal.

${ }^{2}$ Instituto Politécnico de Viseu, Escola Superior de Saúde, Viseu, Portugal.

\begin{abstract}
Objective: Evaluating the quality of life of Portuguese patients with schizophrenia and linking it to sociodemographic and clinical aspects. Method: A quantitative crosssectional study carried out with individuals affected by schizophrenia, living in the entire continental territory of Portugal, through application of a sociodemographic and clinical questionnaire and the Quality of Life Scale short version (QLS PT). Parametric and non-parametric tests were performed to evaluate the correlation between variables. Results: The sample consisted of 282 participants. The results point to a better quality of life for individuals living in autonomous residences or with their parents, who are employed/students, who have had the disorder for less time and are younger, who have completed the $12^{\text {th }}$ grade of schooling and who are not medicated with first-generation neuroleptics. Conclusion: The results indicate that some sociodemographic and clinical characteristics influence the quality of life of patients with schizophrenia and should be considered in the patient evaluation and in planning appropriate and effective strategies for their psychosocial rehabilitation.
\end{abstract}

\section{DESCRIPTORS}

Schizophrenia; Quality of Life; Population Characteristics; Psychiatric Nursing.
Corresponding author:

Lara Guedes de Pinho

Universidade de Aveiro, Campus

Universitário de Santiago

3810-193 - Aveiro, Portugal

larapinho@ua.pt 


\section{INTRODUCTION}

Quality of life is associated with a person's perception of their well-being, health and satisfaction with their circumstances in life, including access to available resources and opportunities ${ }^{(1)}$. In this sense, when comparing the quality of life of three groups (people without psychopathologies, people with common mental disorders and people with severe mental disorders), the results showed that the quality of life of people with severe mental disorders is significantly lower in relation to the two other groups, as well as their general living conditions (such as employment and social networks) ${ }^{(2)}$.

Schizophrenia is a serious mental disorder ${ }^{(3)}$ and as such, quality of life is significantly low in people suffering from it $^{(1,4)}$. This disorder is considered as one of the main causes of disability among young adults ${ }^{(5)}$.

With psychiatric deinstitutionalization, the quality of life of people with severe mental disorders such as schizophrenia began to be the target of a new array of investigations. However, much is still yet to be discovered, since the results of the various studies carried out in different populations differ from each other, and have not generated consensus. These studies focus on the relationship between the concept of quality of life and sociodemographic, economic and clinical data, and the social and occupational functioning of this population ${ }^{(6)}$.

Most recent studies focus on the relationship between quality of life and the disorder symptomatology, relating positive, negative, depression and anxious symptoms to a poorer quality of life ${ }^{(4,6-9)}$. Other studies also address the relationship between sociodemographic characteristics, including age, employment/occupation, living conditions and quality of life $\mathrm{e}^{(10-11)}$.

In a study analyzing sociodemographic, clinical, psychopathological, neurocognitive and psychosocial factors of patients with schizophrenia and their relationship with quality of life, psychosocial and psychopathological factors were the ones that most influenced this variable, followed by clinical and sociodemographic variables. Sociodemographic factors evaluated were gender, age, education, marital status and professional/employment status, and only marital status and professional/employment status obtained significant results. Thus, being married and employed positively influenced the quality of life. Clinical factors were medication, disorder duration, number of hospitalizations and presence of a subtype diagnosis of paranoia. The number of hospitalizations influenced the quality of life ${ }^{(11)}$.

Developing intervention strategies in the schizophrenia area is facilitated by identifying factors that influence quality of life, which can be adjusted to the population characteristics in order to establish patient recovery.

In Portugal, the investigations in this area are still underdeveloped, and as far as we know there are no Portuguese studies with a sample that is comprised from the North to the South of the country, while only one Portuguese study correlating the quality of life of these patients with the symptomatology and social functioning was found ${ }^{(7)}$.

Thus, the objective of this study is to evaluate the quality of life of Portuguese patients with schizophrenia, and relate it to socio-demographic and clinical aspects.

\section{METHOD}

This is a quantitative transversal study. A favorable opinion was obtained for the present investigation from the National Data Protection Commission (authorization number 843/2015), as well as from the ethics committee of all the institutions involved. All ethical principles arising from any investigation were met, as well as obtaining participants' informed consent, confidentiality and anonymity. Data collection was performed over a period of 15 months (from January 2015 to March 2016).

\section{SAMPLE}

The study population was composed of individuals of Portuguese nationality with a diagnosis of schizophrenia and living in mainland Portugal. Participants were selected according to the following criteria: diagnosis of schizophrenia (ICD-10 criteria) and being in contact with the community, regardless of whether or not they were institutionalized (with regular leave to visit). Exclusion criteria considered were: being diagnosed with oligophrenia, having active psychotic symptomatology that impedes understanding the objectives of the investigation, or refusing to participate at any moment of the investigation. The sample selection was carried out in nine hospital institutions from the North to South of the country, with five public and four private. Regarding the public hospitals, two correspond to central psychiatric hospitals, one in the north and one in the south. These hospitals currently have an outpatient service (outpatient and psychosocial rehabilitation) and acute inpatient care. The remaining three correspond to psychiatry departments inserted in general hospitals, in the north, center and south, respectively, which also include outpatient and acute inpatient care services. Within the selected private institutions, three correspond to religious psychiatric institutions with short, medium and long-term hospitalization and psychosocial rehabilitation activities, and one corresponds to a socio-occupational forum. The sample was non-probabilistic by convenience. Participants in the study were referred by the assistant psychiatrist; out of a total of 354 individuals who met the criteria, 72 refused to participate. Thus, the sample consisted of 282 participants, where 136 belonged to the outpatient hospital service, 68 to the psychosocial rehabilitation service, and 78 to the inpatient service $(28$ in acute hospitalization, in the stabilization phase, and 50 institutionalized in a hospital institution). Thus $48.2 \%$ of the individuals are only treated by outpatient consultations, and $51.8 \%$ have daily/weekly follow-ups with psychiatric professionals, either in psychosocial rehabilitation services or in acute/chronic hospitalization. Therefore, with this selection we consider having a representative population sample from different contexts.

\section{Procedure}

After all the ethical principles were formalized, an individual interview was conducted in a private office with each participant for sociodemographic and clinical data collection and to apply the reduced version of the Portuguese 
Quality of Life Scale (QLS $-\mathrm{PT})$. Evaluation instruments were filled out by the researcher and were selected according to the objectives of the present study and the characteristics of the study population. The sociodemographic and clinical questionnaire was specifically designed for this study, with the objective of characterizing both sociodemographic and clinical levels. Sociodemographic data collected were: gender, age, marital status, education level, cohabitation, country region and professional/employment status. The clinical data were: duration of mental disorder, number of Psychiatric hospitalizations, oral and injectable medication, type of treatment and substance use (current and past).

The measuring instrument used to assess quality of life was the $\mathrm{QLS}_{7}-\mathrm{PT}$ comprised of 7 items. Each item is composed of a seven-point Likert scale with values of 5 and 6 indicating normal functioning, 2 to 4 revealing a considerable loss, and 0 and 1 reflecting serious impairment in the evaluated item. This instrument assesses the functioning of patients with schizophrenia, taking into account negative symptoms regardless of the presence or absence of positive symptomatology, both in its original version ${ }^{(12)}$ and in its short version $^{(13)}$.

\section{Data analysis}

Collected data were analyzed in the SPSS program (Statistical Package for Social Sciences) version 22.0 for Windows. Analysis of variance (ANOVA), post hoc Tukey test, t-test and Kruskal-Wallis test were performed in order to evaluate the differences between socio-demographic data (gender, age, schooling, marital status, cohabitation, professional/employment status, country region), clinical characteristics (number of hospitalizations, disorder duration, type of antipsychotic medication, type of treatment/followup and substance use) and quality of life. These analyzes were performed after verifying the normality of the overall data using the Kolmogorov-Smirnov test for samples with dimension $>30$, the Shapiro-Wilk test for samples $<30$, and homogeneity through the Levene test.

\section{RESULTS}

The sample consisted of 282 individuals diagnosed with schizophrenia (39.7\% female and $60.3 \%$ male), with a mean age of 46.15 years $( \pm 13.126)$ and between the ages of 20 and 78 years. Of the participants, $49.29 \%$ had the disorder for less than 20 years, they were mostly single (67.4\%), and $24.1 \%$ were hospitalized six or more times. No statistically significant differences were obtained after the correlation test to verify whether there were differences between those hospitalized up to five times and those hospitalized six or more times. This can be explained by the reduced number of hospitalized patients six or more times (24.1\%), since it would be expected that the higher the number of hospitalizations, the worse the quality of life.

Sociodemographic and clinical data of the study sample are presented in Tables 1, 2 and 3.
Table 1 - Sociodemographic characterization of the participants - Continental Portugal, 2015-2016.

\begin{tabular}{|c|c|c|}
\hline Variables & $\mathbf{N}$ & $\%$ \\
\hline \multicolumn{3}{|l|}{ Country Region } \\
\hline North & 98 & 34.8 \\
\hline Center & 75 & 26.6 \\
\hline South & 109 & 38.7 \\
\hline \multicolumn{3}{|l|}{ Service } \\
\hline Outpatient consultations & 136 & 48.2 \\
\hline Psychosocial Rehabilitation & 68 & 24.1 \\
\hline Chronic/acute hospitalization & 78 & 27.7 \\
\hline \multicolumn{3}{|l|}{ Gender } \\
\hline Female & 112 & 39.7 \\
\hline Male & 170 & 60.3 \\
\hline \multicolumn{3}{|l|}{ Schooling } \\
\hline $1^{\text {st }}$ cycle of Basic Education (BE) or lower & 75 & 26.6 \\
\hline $2^{\text {nd }}$ cycle of BE & 63 & 22.3 \\
\hline $3^{\text {rd }}$ cycle of BE & 69 & 24.5 \\
\hline Secondary education ( $12^{\text {th }}$ grade) & 54 & 19.1 \\
\hline Higher education & 21 & 7.4 \\
\hline \multicolumn{3}{|l|}{ Marital status } \\
\hline Single & 190 & 67.4 \\
\hline Married/Stable Union & 40 & 14.2 \\
\hline Divorced/Separated/Widower & 52 & 18.4 \\
\hline \multicolumn{3}{|l|}{ Cohabitation } \\
\hline Parents/ Father/ Mother & 105 & 37.2 \\
\hline Alone & 54 & 19.1 \\
\hline Institution & 52 & 18.4 \\
\hline Spouse/Partner & 38 & 13.5 \\
\hline Kids and/other & 24 & 8.5 \\
\hline Autonomous residence & 9 & 3.2 \\
\hline \multicolumn{3}{|l|}{ Professional/employment status } \\
\hline Employed/Student & 26 & 9.2 \\
\hline Not active/Unemployed & 82 & 29.1 \\
\hline Disabled & 174 & 61.7 \\
\hline
\end{tabular}

Table 2 - Clinical characterization of the participants - Continental Portugal, 2015-2016.

\begin{tabular}{lcc}
\hline Variables & N & $\%$ \\
\hline Disorder duration & & \\
$\quad<5$ years & 43 & 15.2 \\
5 to 10 years & 35 & 12.4 \\
$\quad 10$ to 20 years & 61 & 21.6 \\
$\quad>20$ years & 143 & 50.7 \\
Number of Psychiatric hospitalizations & & \\
$\quad$ None & 22 & 7.8 \\
$\quad 1$ & 67 & 23.8 \\
2 to 5 & 125 & 44.3 \\
$\quad 6$ to 10 & 43 & 15.2 \\
$\quad>10$ & 25 & 8.9 \\
Hospitalized for less than 1 year & & \\
$\quad$ Yes & 98 & 34.8 \\
$\quad$ No & 184 & 65.2 \\
Neuroleptic medication & & \\
$\quad 1^{\text {st }}$ generation & 41 & 14.5 \\
$\quad 2^{\text {nd }}$ generation & 127 & 45.0 \\
$1^{\text {st }}$ and $2^{\text {nd }}$ generation & 114 & 40.4 \\
\hline
\end{tabular}

continued... 


\begin{tabular}{lcc}
...continuation & & \\
\hline Variables & $\mathrm{N}$ & $\%$ \\
\hline $\begin{array}{l}\text { Current follow-up } \\
\quad \text { Only consultations with the Psychiatrist }\end{array}$ & 34 & 12.1 \\
$\quad \begin{array}{l}\text { Consultations with the Psychiatrist and another } \\
\text { professional (nurse and/or psychologist) }\end{array}$ & 123 & 43.6 \\
$\quad$ Psychosocial Rehabilitation & 125 & 44.3 \\
$\begin{array}{l}\text { Current substance use } \\
\quad \text { Yes }\end{array}$ & 148 & 52.5 \\
$\quad$ No & 134 & 47.5 \\
History of substance use & & \\
$\quad$ Yes & 186 & 66.0 \\
$\quad$ No & 96 & 34.0 \\
\hline
\end{tabular}

Regarding the sociodemographic data, no statistically significant differences were found in the following factors: gender, marital status or region of the country. In relation to clinical data, no statistically significant differences were observed in the following factors: type of treatment/followup or substance use. Thus, Table 3 shows the results of the non-parametric psychometric tests for the variables of cohabitation $(p=0.044)$, professional status $(p<0.001)$ and disorder duration ( $p=0.002$ ), while Table 4 shows parametric ANOVA tests and $t$-test with the results for the variables age $(p<0.001)$, education $(p=0.016)$, psychiatric hospitalizations $(p=0.05)$, and $1^{\text {st }}$ generation neuroleptic medication $(p=0.022)$.

Table 3 - Results of non-parametric test analysis (Kruskal-Wallis test) for QLS_-PT - Continental Portugal, 2015-2016.

\begin{tabular}{|c|c|c|c|c|}
\hline & $\mathbf{N}$ & Mean Rank & Chi-square & p-value \\
\hline \multicolumn{5}{|l|}{ Cohabitation } \\
\hline Autonomous residence & 9 & 208.00 & \multirow{6}{*}{11.428} & \multirow{6}{*}{0.044} \\
\hline Parents/ Father /Mother & 105 & 147.61 & & \\
\hline Alone & 54 & 141.16 & & \\
\hline Institution & 52 & 139.24 & & \\
\hline Spouse/Partner+Kids & 38 & 134.86 & & \\
\hline Kids/others & 24 & 106.02 & & \\
\hline \multicolumn{5}{|l|}{ Professional/employment status } \\
\hline Employed/Student & 26 & 231.40 & \multirow{3}{*}{37.545} & \multirow{3}{*}{0.000} \\
\hline Not active/ Unemployed & 82 & 144.51 & & \\
\hline Disabled & 174 & 126.65 & & \\
\hline \multicolumn{5}{|l|}{ Duration of the disorder } \\
\hline$<5$ years & 43 & 179.28 & \multirow{4}{*}{14.389} & \multirow{4}{*}{0.002} \\
\hline 5 to 10 years & 35 & 151.56 & & \\
\hline 10 to 20 years & 61 & 143.30 & & \\
\hline$>20$ years & 143 & 126.91 & & \\
\hline
\end{tabular}

Table 4 - Parametric test results for QLS - PT - Continental Portugal, 2015-2016.

\begin{tabular}{|c|c|c|c|c|c|c|}
\hline & $\mathbf{N}$ & Mean & Standard deviation (SD) & $t^{*}$ & $\mathbf{F}^{* *}$ & p-value \\
\hline \multicolumn{7}{|l|}{ Age } \\
\hline 20-30 & 39 & 4.44 & 1.067 & & \multirow{5}{*}{5.892} & \multirow{5}{*}{0.000} \\
\hline $31-40$ & 62 & 3.87 & 0.982 & & & \\
\hline $41-50$ & 75 & 3.82 & 1.020 & & & \\
\hline $51-60$ & 60 & 3.79 & 0.993 & & & \\
\hline$>60$ & 46 & 3.38 & 0.976 & & & \\
\hline \multicolumn{7}{|l|}{ Schooling } \\
\hline $1^{\text {st }}$ cycle of BE or lower & 75 & 3.61 & 1.033 & & \multirow{4}{*}{3.477} & \multirow{4}{*}{0.016} \\
\hline $2^{\text {nd }}$ and $3^{\text {rd }}$ cycle of BE & 132 & 3.82 & 0.965 & & & \\
\hline Secondary education & 54 & 4.20 & 1.099 & & & \\
\hline Higher education & 21 & 3.78 & 0.888 & & & \\
\hline \multicolumn{7}{|l|}{ Psychiatric hospitalizations } \\
\hline Yes & 260 & 3.80 & 1.033 & \multirow{2}{*}{-1.965} & & \multirow[b]{2}{*}{0.050} \\
\hline No & 22 & 4.25 & 1.063 & & & \\
\hline \multicolumn{7}{|l|}{ Hospitalized in the last year } \\
\hline Yes & 98 & 2.99 & 1.634 & \multirow{2}{*}{-1.967} & & \multirow{2}{*}{0.050} \\
\hline No & 184 & 3.40 & 1.682 & & & \\
\hline \multicolumn{7}{|l|}{$1^{\text {st }}$ generation Neuroleptic } \\
\hline Yes & 155 & 3.71 & 0.989 & \multirow{2}{*}{-2.302} & & \multirow{2}{*}{0.022} \\
\hline No & 127 & 3.99 & 1.083 & & & \\
\hline
\end{tabular}

*t-test. **ANOVA test. 
An analysis of the results with statistically significant differences shows that the $\mathrm{QLS}_{7}-\mathrm{PT}$ scale results were higher for users living in autonomous residences (Mean Rank=208.00) and lower for those living with their kids and/or others (Mean Rank=106.02).

Regarding professional/employment status, those who were employed/students had higher results (Mean Rank=231.40) when compared to non-active (Mean Rank=144.51) or those who were disabled (Mean Rank=126.65).

With regard to disorder duration, those who have had it for longer are those that have lower values in the $\mathrm{QLS}_{7}-\mathrm{PT}$ scale (Mean Rank=126.91).

In relation to age, statistically significant differences were obtained, and the higher the age, the lower the $\mathrm{QLS}_{7}-\mathrm{PT}$ scale values $(p<0.001)$.

Regarding schooling, those who obtained the worse results on the $\mathrm{QLS}_{7}-\mathrm{PT}$ scale were those who had only completed up to the $4^{\text {th }}$ grade or lower $(x=3.61, \sigma=1.033)$, while the best results were from participants who had completed their $12^{\text {th }}$ grade of schooling $(x=4.20, \sigma=1.099)$.

Although it cannot be stated that there are statistically significant differences regarding the presence or absence of at least one hospitalization in the Psychiatry department, and hospitalization in the last year, as $p=0.050$, we chose to present these results given the proximity of $p<0.050$. Thus, those who were never hospitalized had better scores on the $\mathrm{QLS}_{7}-\mathrm{PT}$ scale ( $\left.\mathrm{x}=3.40, \sigma=1.682\right)$, as well as those whose last hospitalization was more than 1 year ago $(x=3.40 ; \sigma=1.682)$.

Regarding the use of first-generation neuroleptics, statistically significant results were obtained, where those who were not medicated with these neuroleptics obtained higher results on the $\mathrm{QLS}_{7}-\mathrm{PT}$ scale $(\mathrm{x}=3.99, \sigma=1.083)$.

\section{DISCUSSION}

This study highlights the low quality of life of individuals with schizophrenia. Regarding education, the data indicate that individuals who had only completed up to their $4^{\text {th }}$ year of schooling or lower are those with the worst quality of life, while the ones with the best quality of life are those who completed their $12^{\text {th }}$ year of schooling. We emphasize the fact that the participants with higher education have a worse quality of life than those who have up to the $6^{\text {th }}, 9^{\text {th }}$ or $12^{\text {th }}$ year of schooling, being only above those who completed up to their $4^{\text {th }}$ year or lower.

Regarding professional/employment status, the results are congruent with other studies where those who were employed/students obtained higher $\mathrm{QLS}_{7} \mathrm{PT}$ scores when compared to the non-active or disabled individuals. These conclusions corroborate those of other studies that focus on the importance of occupational activity in the quality of life of people with schizophrenia ${ }^{(10,14-16)}$. In view of these facts, being active seeking work, as well as implementing protected jobs and raising awareness of employers about the importance of inserting people with this pathology into the workplace is crucial for rehabilitation of these patients. Thus, developing occupational programs and opportunities for this population should be one of the areas for investment in the severe mental disorder area. Also along these lines, a meta-analysis ${ }^{(17)}$ found eight studies regarding the influence of employment on the quality of life of these individuals, with a positive correlation between quality of life and having employment.

Concerning cohabitation, the data points to a better quality of life among participants living in autonomous residences. Considering that those living in autonomous residences are those who are in the final stages of the psychosocial rehabilitation process, we can conclude that this type of intervention is important for the autonomy of the person with schizophrenia and their adequate, effective insertion supported by the community. Those living with their parents/ father/mother (37.2\%) had the second best results on the $\mathrm{QLS}_{7} \mathrm{PT}$ scale. Bringing together those living with parents/ father/mother and those living with a spouse/partner, we observed that the majority of the sample lived with family members (50.7\%). Thus, developing psychoeducation programs for family members is fundamental ${ }^{(18-20)}$. People with schizophrenia who lived in institutions had worse quality of life than those who lived alone or with family members ${ }^{(21)}$. A study in which the participants lived in their own home demonstrated better access to opportunities and resources to improve their quality of life than those living in institutions ${ }^{(22)}$. Thus, when the individual has a strong desire to live in their own home, they become more motivated for rehabilitation. A result that negatively surprised us was the relationship between the quality of life of the individuals who lived with a spouse/partner, as we expected it to be higher since several studies have indicated that patients with a partner have better quality of life ${ }^{(16)}$.

We also found that the higher the age, the longer the duration of the disorder, and the lower the quality of life. These results confirm that degradation of a person with schizophrenia throughout the course of the disorder leads to a worse quality of life. A study that also used QLS found similar results that a longer duration of the disorder and an older age would be associated with a worse quality of life $\mathrm{e}^{(21)}$. In this sense, another study showed that a longer duration of the disorder was a predictor for worse quality of life, despite age not being significantly related to quality of life ${ }^{(15)}$.

Regarding medication, participants who received firstgeneration neuroleptics had worse results on the quality of life scale than those who were only receiving second-generation neuroleptics, indicating that this type of neuroleptic may negatively influence the quality of life. Similar results were found in another investigation which took place in Germany, with a sample of 149 individuals with schizophrenia divided into two groups. One group was treated with first-generation neuroleptics $(n=69)$, and another group was treated with second-generation neuroleptics $(n=80)$ over 24 months. The results indicated that improvement in the quality of life throughout the treatment was significantly superior in the group medicated with second generation neuroleptics ${ }^{(23)}$.

Concerning psychiatric hospitalizations, data indicate that those who have never been hospitalized have a higher quality of life than those who have had at least one inpatient hospitalization. Moreover, participants who were hospitalized in the year prior to data collection also had worse results 
on the quality of life scale. In this sense, in a study of 1,020 individuals with schizophrenia which compared quality of life with relapses in a 24-month period, it was found that the higher the quality of life level, the lower the relapse rate ${ }^{(24)}$.

As limitations of the present investigation, we can point out the reduced size of the sample and the lack of data regarding the family elements and their affective and significant relationships, as well as their sociodemographic characteristics, quality of life and degree of overload/burnout.

\section{CONCLUSION}

This study evidences the relevant influences of some sociodemographic and clinical characteristics on the quality of life of individuals with schizophrenia. In relation to sociodemographic data, the results indicate that factors such as age, cohabitation, professional/employment status and education influence the quality of life of these patients. Regarding clinical data, it was found that duration of the disorder, the presence of at least one inpatient psychiatry or hospitalization in the previous year, and the use of first generation neuroleptics influence the quality of life.
This study reinforces the importance of developing nursing activities that promote patient with schizophrenia's autonomy, having an occupation and early follow-up of the patients in order to prevent degrading their quality of life from progression of the mental disorder. Thus, it is essential to implement an action plan that seeks to promote the autonomy of these individuals and their insertion in society. This study reinforces the importance of the work developed by the community mental health teams, which should be continued in order to avoid the quality of life of these patients diminishing from schizophrenia evolution and it should start from the moment of the first psychotic episode.

Further studies that address the relationship between age, mental disorder duration and use of first/second generation neuroleptics, and their impact on quality of life of individuals with schizophrenia are suggested. Another suggestion is to develop a research study that addresses the relationship between employment, occupation and income to understand if what improves quality of life is having an occupation or the income coming from it; and also to address in the future the relationship between paternal affection and quality of life.

\section{RESUMO}

Objetivo: Avaliar a qualidade de vida dos indivíduos portugueses com esquizofrenia e relacioná-la com aspetos sociodemográficos e clínicos. Método: Estudo quantitativo de natureza transversal realizado com portadores de esquizofrenia, residentes em todo o território continental de Portugal, tendo sido aplicado um questionário sociodemográfico e clínico e a Quality of Life Scale versão reduzida $\left(\mathrm{QLS}_{7} \mathrm{PT}\right)$. Foram realizados testes paramétricos e não paramétricos para avaliar a correlação entre as variáveis. Resultados: A amostra foi constituída por 282 participantes. Apontam para uma melhor qualidade de vida os indivíduos que vivem em residências autônomas ou com os pais, empregados/estudantes, com transtorno há menos tempo e menor idade, com o $12^{\circ}$ ano de escolaridade e não medicados com neurolépticos de primeira geração. Conclusão: Os resultados indicam que algumas características sociodemográficas e clínicas influenciam a qualidade de vida dos indivíduos com esquizofrenia, pelo que devem ser consideradas na avaliação psiquiátrica e no planejamento das estratégias adaptadas e eficazes à sua reabilitação psicossocial.

\section{DESCRITORES}

Esquizofrenia; Qualidade de Vida; Características da População; Enfermagem Psiquiátrica.

\section{RESUMEN}

Objetivo: Evaluar la calidad de vida de los individuos portugueses con esquizofrenia y relacionarla con aspectos sociodemográficos y clínicos. Método: Estudio cuantitativo de naturaleza transversal realizado con portadores de esquizofrenia, residentes en todo el territorio continental de Portugal, habiendo sido aplicado un cuestionario sociodemográfico y clínico y la Quality of Life Scale versión reducida $\left(\mathrm{QLS}_{7} \mathrm{PT}\right)$. Se realizaron pruebas paramétricas y no paramétricas para evaluar la correlación entre las variables. Resultados: La muestra fue constituida por 282 participantes. Los resultados apuntan a una mejor calidad de vida de quienes residen en residencias autónomas o con los padres, los empleados / estudiantes, con trastorno por menos tiempo y menor edad, con 12 años de escolaridad y no medicados con neurolépticos de primera generación. Conclusión: Los resultados indican que algunas características sociodemográficas y clínicas influyen en la calidad de vida de los individuos con esquizofrenia, por lo que deben ser consideradas en la evaluación psiquiátrica y en la planificación de las estrategias adaptadas y eficaces a su rehabilitación psicosocial.

\section{DESCRIPTORES}

Esquizofrenia; Calidad de Vida; Características de la Población; Enfermería Psiquiátrica.

\section{REFERENCES}

1. Medici CR, Vestergaard CH, Hjorth P, Hansen MV, Shanmuganathan JW, Viuff AG, et al. Quality of life and clinical characteristics in a nonselected sample of patients with schizophrenia. Int J Soc Psychiatry. 2015;62(1):12-20. DOI: 10.1177/0020764015585330.

2. Evans S, Banerjee S, Leese M, Huxley P. The impact of mental illness on quality of life: a comparison of severe mental illness, common mental disorder and healthy population samples. Qual Life Res. 2007;16(1):17-29. DOI: 10.1007/s11136-006-9002-6

3. World Health Organization. International Classification of Diseases (ICD) [Internet]. Geneva: WHOS; 2013 [cited 2016 Dec 2] Available from: http://www.who.int/classifications/icd/en/

4. Alessandrini M, Lançon C, Fond G, Faget-Agius C, Richieri R, Faugere M, et al. A structural equation modelling approach to explore the determinants of quality of life in schizophrenia. Schizophr Res. 2016;171(1-3):27-34. DOI:10.1016/j.schres.2016.01.012. 
5. Xavier M, Baptista H, Mendes J, Magalhães P, Caldas-de-Almeida J. Implementing the World Mental Health Survey Initiative in Portugal: rationale, design and fieldwork procedures. Int J Ment Health Syst. 2013;7(1):19.

6. Gómez-de-Regil L. Curso de la enfermedad y calidad de vida en pacientes mexicanos con psicosis. Rev Psiquiatr Salud Ment. 2015;8(4):21823. DOI: 10.1016/j.rpsmen.2013.12.002

7. Brissos S, Balanzá-Martinez V, Dias VV, Carita AI, Figueira ML. Is personal and social functioning associated with subjective quality of life in schizophrenia patients living in the community? Eur Arch Psychiatry Clin Neurosci. 2011;261(7):509-17. DOI: 10.1007/s00406011-0200-z

8. Gorna K, Jaracz K, Jaracz J, Kiejda J, Grabowska-Fudala B, Rybakowski J. Social functioning and quality of life in schizophrenia patients-relationship with symptomatic remission and duration of illness. Psychiatr Pol. 2014;48(2):277-88.

9. Song YY, Kim KR, Park JY, Lee SY, Kang JI, Lee E, et al. Associated factors of quality of life in first-episode schizophrenia patients. Psychiatry Investig. 2011;8(3):201-6. DOI: 10.4306/pi.2011.8.3.201.

10. Cesari L, Bandeira M. Avaliação da qualidade de vida e percepção de mudança em pacientes com esquizofrenia. J Bras Psiquiatr. 2010;59(4):293-301.

11. Chou CY, Ma MC, Yang TT. Determinants of subjective health-related quality of life (HRQoL) for patients with schizophrenia. Schizophr Res. 2014;154(1-3):83-8. DOI: 10.1016/j.schres.2014.02.011.

12. Heinrichs DW, Hanlon TE, Carpenter WT. The Quality of Life Scale: an instrument for rating the schizophrenic deficit syndrome. Schizophr Bull. 1984;10(3):388-98. DOI: 10.1093/schbul/10.3.388

13. Fervaha G, Remington G. Validation of an abbreviated quality of life scale for schizophrenia. Eur Neuropsychopharmacol. 2013;23(9):10727. DOI: 10.1016/j.euroneuro.2012.11.009

14. Rosenheck R, Leslie D, Keefe R, McEvoy J, Swartz M, Perkins D, et al. Barriers to employment for people with schizophrenia. Am J Psychiatry. 2006;163(3):411-7. DOI: 10.1176/appi.ajp.163.3.411

15. Hsiao CY, Hsieh MH, Tseng CJ, Chien SH, Chang CC. Quality of life of individuals with schizophrenia living in the community: relationship to socio-demographic, clinical and psychosocial characteristics. J Clin Nursing. 2012;21(15-16):2367-76. DOI: 10.1111/j.13652702.2012.04067.x

16. Othman Z, Ghazali M, Razak AA, Husain M. Severity of tardive dyskinesia and negative symptoms are associated with poor quality of life in schizophrenia patients. Int Med J. 2013;20(6):677-80.

17. Bouwmans C, Sonneville C, Mulder CL, Hakkaart-van Roijen L. Employment and the associated impact on quality of life in people diagnosed with schizophrenia. Neuropsychiatr Dis Treat. 2015;11:2125-42. DOI: 10.2147/NDT.S83546.

18. Pinho LM, Pereira AM. Intervenção familiar na esquizofrenia: redução da sobrecarga e emoção expressa. Rev Port Enferm Saúde Mental. 2015;(14):15-23. DOI: 10.19131/rpesm.0101

19. Caqueo-Urízar A, Rus-Calafell M, Urzúa A, Escudero J, Gutiérrez-Maldonado J. The role of family therapy in the management of schizophrenia: challenges and solutions. Neuropsychiatr Dis Treat. 2015;11:145-51. DOI: 10.2147/NDT.S51331.

20. Sin J, Norman I. Psychoeducational interventions for family members of people with schizophrenia: a mixed-method systematic review. J Clin Psychiatry. 2013;74(12):1145-62. DOI: 10.4088/JCP.12r08308.

21. Browne S, Roe M, Lane A, Gervin M, Morris M, Kinsella A, et al. Quality of life in schizophrenia: relationship to sociodemographic factors, symptomatology and tardive dyskinesia. Acta Psychiatr Scand. 1996;94(2):118-24. DOI: 10.1111/j.1600-0447

22. Browne G, Courtney M. Exploring the experience of people with schizophrenia who live in boarding houses or private homes: a grounded theory study. Contemp Nurse. 2005;18(3):233-46. DOI: 10.5172/conu.18.3.233

23. Gründer G, Heinze M, Cordes J, Mühlbauer B, Juckel G, Schulz C, et al. Effects of first-generation antipsychotics versus second-generation antipsychotics on quality of life in schizophrenia: a double-blind, randomised study. Lancet Psychiatry. 2016;3(8):717-29. DOI: 10.1016/ S2215-0366(16)00085-7

24. Boyer L, Millier A, Perthame E, Aballea S, Auquier P, Toumi M. Quality of life is predictive of relapse in schizophrenia. BMC Psychiatry. 2013;13:15. DOI: 10.1186/1471-244X-13-15 